DOI: $10.19195 / 0137-1134.114 .10$

\author{
WIESŁAWA MIEMIEC \\ Uniwersytet Wrocławski \\ wieslawa.miemiec@uwr.edu.pl \\ MARCIN MIEMIEC \\ Uniwersytet Wrocławski \\ marcin.miemiec@uwr.edu.pl
}

\title{
ORGANIZACJA ORAZ FINANSOWANIE PUBLICZNEGO RADIA I TELEWIZJI W REPUBLICE FEDERALNEJ NIEMIEC
}

\begin{abstract}
Abstrakt: W Republice Weimarskiej i w III Rzeszy radiofonia była zależna od rządu. Republika Federalna Niemiec stworzyła natomiast system prawny, który zapewnił środkom masowego przekazu niezależność prawną i realną. Na ustrój radiofonii i telewizji wpłynęło orzecznictwo Federalnego Sądu Konstytucyjnego. W skład radiofonii i telewizji publicznej wchodzą nadawcy krajowi i wspólni krajów związkowych, zorganizowani jako zakłady publicznoprawne posiadające osobowość prawną. Zarządzanie nadawcami realizowane jest na podobnych zasadach. Rada radiofonii to organ stanowiący i kontrolny, rada administracyjna oraz intendent to organy wykonawcze. Rada radiofonii krajowej składa się z osób delegowanych przez parlament, rząd krajowy, środowiska i organizacje znaczące politycznie, światopoglądowo i społecznie, według klucza ustawowego. Rada Deutschlandradio, korporacji zrzeszającej ARD, ZDF i nadawców krajowych, składa się z przedstawicieli krajów związkowych, rządu federalnego i organizacji społecznych. Rada radiofonii wybiera większość członków rady administracyjnej, wybiera i odwołuje intendenta, wyraża zgodę na obsadę stanowisk kierowniczych nadawcy, uchwala wytyczne programowe, doradza intendentowi w kształtowaniu programu i w innych podstawowych sprawach, zatwierdza plan gospodarczy, podejmuje uchwałę absolutoryjną. Rada administracyjna wspiera rozwój gospodarczy nadawcy, zawiera umowę o pracę z intendentem, rozstrzyga spory między intendentem a nadawcą, czuwa nad prowadzeniem spraw przez intendenta, kontroluje budżet i zamknięcie roczne sporządzone przez intendenta, publikuje bilans i sprawozdanie roczne, podejmuje rozstrzygnięcia w sprawach umów, jeśli nie jest właściwy intendent. Nad nadawcami sprawowany jest nadzór prawny (przez właściwy rząd lub ministra). Podstawowe znaczenie w zakresie czuwania nad przestrzeganiem prawa odgrywa kontrola wewnętrzna sprawowana przez radę radiofonii. Niemiecka radiofonia i telewizja jest finansowana $\mathrm{z}$ danin - początkowo z opłat, a od 1 stycznia 2013 roku ze składek obciążających gospodarstwa domowe. W publicznej radiofonii i telewizji funkcjonuje wyrównanie finansowe. Taki system finansowania zapewnia mediom publicznym niezależność oraz realizację ich ustawowych zadań, w szczególności spełnianie misji publicznej.
\end{abstract}

Słowa kluczowe: radiofonia, telewizja, misja publiczna, umowa państwowa, zakład publicznoprawny, rada radiofonii, rada administracyjna, intendent, opłata, składka 
Opracowanie to poświęcamy naszemu Przyjacielowi, Czcigodnemu Jubilatowi, Prof. dr. hab. Leonowi Kieresowi. Jego zasługi w budowie Rzeczypospolitej Polskiej jako demokratycznego państwa prawnego są powszechnie znane. Dokonał i dokonuje w tym zakresie bardzo wiele na wszystkich polach Jego aktywności, a więc jako uczony, nauczyciel akademicki, samorządowiec, parlamentarzysta oraz sędzia Trybunału Konstytucyjnego.

Życzymy mu jeszcze długiej aktywności z pożytkiem dla nauki i Rzeczypospolitej Polskiej.

Ad multos annos, Szanowny Jubilacie.

Radio i telewizja, począwszy od ich powstania, są istotnym elementem życia społecznego. Są źródłem informacji, edukują, dostarczają rozrywki. Na pluralistycznym rynku medialnym działają nadawcy publiczni i prywatni. Nadawców publicznych wyróżnia misja programowa, zgodnie z którą ich oferta w znaczącej części powinna zawierać treści z zakresu kultury, sztuki, oświaty, nauki czy religii. Właścicielem mediów o takim profilu jest z reguły państwo. Wiąże się z tym ryzyko nieobiektywności, polegające na wykorzystywaniu ich do propagowania ideologii i praktyki aktualnie rządzącej partii czy koalicji.

Media publiczne, w odróżnieniu od prywatnych, ze względu na ich „misyjne” zadania nie powinny być nastawione na osiąganie zysku. Większość ich oferty programowej ma charakter niekomercyjny. Powoduje to konieczność prawnej regulacji ich publicznego finansowania, które z reguły ciąży na abonentach. Obowiązkowy charakter takich obciążeń wywołuje często niezadowolenie społeczne.

Ciekawym przykładem sytuacji prawnej mediów jest państwo niemieckie, w którym radiofonia rozpoczęła działalność prawie sto lat temu. Od początku stała się przedmiotem zainteresowania niemieckich władz państwowych, kolejno - demokratycznych, autorytarnych i ponownie demokratycznych. W latach pięćdziesiątych ubiegłego wieku już w Republice Federalnej Niemiec rozpoczął się rozwój telewizji publicznej. System niemieckiej radiofonii i telewizji stał się dualny przez dopuszczenie do rynku medialnego w połowie lat osiemdziesiątych ubiegłego wieku nadawców prywatnych, jednak przy prawnym i ekonomicznym zabezpieczeniu dalszego istnienia silnej, bezstronnej i programowo niezależnej od państwa radiofonii i telewizji publicznej.

W niniejszym opracowaniu, zważając na jego ograniczone rozmiary, zostanie zwięźle przedstawiona ewolucja niemieckiej publicznej radiofonii i telewizji ${ }^{1}$, a w nieco szerszym zakresie treść współczesnej regulacji prawnej ustroju tych mediów, głównie z punktu widzenia zapewnienia ich niezależności programowej od państwa, a także sposobu ich finansowania.

1 W Niemczech na zbiorcze określenie radiofonii i telewizji używa się na ogół terminu „radiofonia" (Rundfunk). 
Nie podlega dyskusji, że w społeczeństwie uznającym za nadrzędne idee i praktykę demokratyczną media publiczne powinny odgrywać ważną rolę w procesie kształtowania postaw obywatelskich, w ramach wolności słowa, wolności wyrażania poglądów czy wolności środków masowego przekazu. Takie gwarancje są zawarte w art. 54 Konstytucji Rzeczypospolitej Polskiej, a także w jej art. 14 gwarantującym wolność prasy i innych środków masowego przekazu. Równoległą regulację zawiera niemiecka konstytucja federalna, gwarantując w art. 5 wolność wyrażania poglądów, także w środkach masowego przekazu, i w art. 14 sankcjonującym jej nadużycie. Ze względu na ustrój tego państwa takie gwarancje są też zawarte w konstytucjach poszczególnych krajów związkowych.

Gwarancje konstytucyjne są konkretyzowane - czyli rozwijane bądź ograniczane - w ustawach, a także weryfikowane w praktyce władz państwowych, zgodnej bądź niezgodnej z obowiązującym porządkiem prawnym.

Przyjrzyjmy się zatem rozwiązaniom prawnym i praktyce ich stosowania w Niemczech. Niektóre z nich mogłyby być przydatne w Polsce w budowie przyszłej regulacji prawnej tej tak ważnej problematyki, którą są media publiczne. Dotychczas nie zapewniono bowiem ich niezależności od władz państwowych, obiektywności i wystarczającego finansowania dla umożliwienia prawidłowego spełniania ich publicznej misji programowej.

1. W Niemczech radiofonia od jej początków podlegała regulacji prawa telegraficznego, a władztwo emisyjne sprawowała Poczta Rzeszy ${ }^{2}$. Zarządzeniem z dnia 24 października 1923 roku Minister Poczty Rzeszy cofnął zakaz słuchania audycji radiowych. Dało to podstawę do utworzenia w latach 1923-1924 radia o charakterze rozrywkowym. Rozgłośnie regionalne były zorganizowane w formie spółek kapitałowych, którym udzielano licencji emisyjnych ${ }^{3}$. W maju 1925 roku utworzono Towarzystwo Radiowe Rzeszy Sp. z o.o., organizację zrzeszającą początkowo pięć rozgłośni regionalnych. Ministerstwo Poczty Rzeszy uzyskało w tych spółkach po $51 \%$ udziałów i po trzy miejsca w radach nadzorczych ${ }^{4}$.

Po stwierdzeniu przez rząd Rzeszy doniosłości społecznej publicystyki radiowej, w 1926 roku poddano dziewięć istniejących wówczas spółek kapitałowych prowadzących rozgłośnie regionalne ograniczeniom treści emitowanych programów. Następnie prywatnych inwestorów zmuszono do zbycia akcji. W rezultacie w 1932 roku państwo objęło 51\% udziałów w spółkach prowadzących rozgłośnie

2 Gesetz über das Telegraphenwesen des Deutschen Reichs. Vom 6. April 1892, RGB1. s. 467470; Gesetz, betreffend die Abänderung des Gesetzes über das Telegraphenwesen des Deutschen Reichs vom 6. April 1892. Vom 7. März 1908, s. 79,80, teksty jedn. Reichgesetzblatt (RGB1.) 1928, s. 8, BGB1. 1977, I, s. 459. Ustawa ta, nowelizowana oraz stopniowo zastępowana nowymi ustawami, szczególnie ustawą z dnia 17 grudnia 1997 r. o telekomunikacji (Telekommunikationsgesetz), BGBl. I, s. 3108, obowiązywała do 31 grudnia 2001 r.

3 A. Hesse, Rundfunkrecht, München 1999, s. 3.

4 Towarzystwo istniało do $1945 \mathrm{r}$. 
regionalne, a krajom związkowym przypadło pozostałe 49\%. Taka struktura kapitałowa istniała także w Towarzystwie Radiowym Rzeszy ${ }^{5}$. Do rozgłośni wprowadzono komisarzy rządowych, powoływanych przez rządy krajów związkowych w porozumieniu z ministrem spraw wewnętrznych Rzeszy, czuwających nad treścią programów. Ich zwierzchnikiem został nowo powołany komisarz Rzeszy do spraw radia, podporządkowany ministrowi spraw wewnętrznych. Tak zakończył się spór między Pocztą Rzeszy, broniącą neutralności politycznej radiofonii, a rządem Rzeszy, zmierzającym do wykorzystania jej w celach politycznych. Rządowe wytyczne programowe z dnia 18 listopada 1932 roku były zlepkiem haseł chrześcijańsko-konserwatywnych i nacjonalistycznych ${ }^{6}$. Zobowiązano rozgłośnie do pracy nad odbudową narodu i państwa. W ten sposób radio stało się instrumentem propagandy rządowej ${ }^{7}$. Już przed przejęciem władzy przez partię nazistowską stworzono więc w Niemczech scentralizowaną strukturę radiofonii publicznej podporządkowaną ministrowi spraw wewnętrznych ${ }^{8}$.

Po przejęciu władzy przez nazistów w 1933 roku wraz z likwidacją krajów związkowych przeniesiono na państwo własność udziałów krajów w spółkach prowadzących rozgłośnie regionalne ${ }^{9}$. Rozwiązano rozgłośnie regionalne i przekształcono je w oddziały Radia Rzeszy. Na mocy rozporządzenia z dnia 30 czerwca 1933 roku utworzono Ministerstwo Oświecenia Narodowego i Propagandy Rzeszy, któremu podporządkowano radiofonię ${ }^{10}$. Na podstawie ustawy z dnia 22 września 1933 roku o Izbie Kultury Rzeszy ${ }^{11}$ jako jedną z siedmiu izb branżowych utworzono korporację - Izbę Radiofonii Rzeszy, do której przyjęto zweryfikowanych pracowników radia. Tak zakończono czystkę personalną w radiofonii ${ }^{12}$.

Ostatnim etapem opanowania radiofonii przez reżim nazistowski było przejęcie radiosłuchaczy. Służyło temu zorganizowanie systemu przekazu radiowego, począwszy od 1934 roku, za pośrednictwem tak zwanych odbiorników ludowych. Umożliwiały one w zasadzie jedynie odbiór radia niemieckiego, gdyż nie odbierały audycji na falach krótkich. W uzupełnieniu rozwiązań technicznych w 1939 roku wydano rozporządzenie w sprawie nadzwyczajnych środków radiofonicznych. Przewidywało ono surowe kary za słuchanie zagranicznych stacji radiowych, w tym karę śmierci ${ }^{13}$.

5 H. Brack, Die Organisation der überordneten Aufgaben des Rundfunks, [w:] H. Brack, G. Herrmann, H.-P. Hilling, Organisation des Rundfunks 1948-1962, Hamburg 1962, s. 12-13.

${ }^{6}$ H. Bausch, Der Rundfunk im politischen Kräftespiel der Weimarer Republik 1923-1933, Tübingen 1956, s. $212 \mathrm{n}$.

7 H. Pohle, Der Rundfunk als Instrument der Politik, Hamburg 1955, s. 136.

8 A. Hesse, op. cit., s. 6.

9 E. Bremer, M. Esser, M. Hoffmann, Der Rundfunk in der Verfassungs- und Wirtschaftsordnung in Deutschland, Baden-Baden 1992, s. 18.

10 RGB1. 1933 I, s. 449.

11 RGBl. 1933 I, s. 797.

12 A. Hesse, op. cit., s. 7.

13 RGBl. 1939 I, s. 1683. 
Radiofonię niemiecką od początku finansowali abonenci usług — w postaci opłat traktowanych jako świadczenia wzajemne za udzielenie pozwolenia na posiadanie i użytkowanie odbiornika radiowego. Uregulowały to szczegółowo Przepisy o radiofonii z dnia 27 listopada 1931 roku $^{14}$. Od końca inflacji opłata wynosiła 2 marki miesięcznie. Była pobierana przez Pocztę Rzeszy, która początkowo zatrzymywała $40 \%$, a później $60 \%$ kwoty opłat. Resztę przekazywała poszczególnym spółkom emisyjnym odpowiednio do liczby ich słuchaczy. Rozgłośnie uzyskiwały też niewielkie wpływy z reklam ${ }^{15}$. Wysokość opłaty utrzymała się prawie pięćdziesiąt lat — aż do 1 stycznia 1970 roku, kiedy podwyższono ją o 50 fenigów $^{16}$.

2. Po 1945 roku radio, a potem telewizję, organizowano już w formie publicznoprawnej. Wykluczono możliwość funkcjonowania nadawców prywatnych między innymi dlatego, że brakowało wolnych częstotliwości. Tak jak w innych dziedzinach kształtowania nowej, demokratycznej organizacji życia publicznego Niemiec Zachodnich kierowano się rozwiązaniami prawnymi zaczerpniętymi z porządku prawnego zachodnich mocarstw okupacyjnych. W tym przypadku wzorcem stało się brytyjskie radio BBC (British Broadcasting Corporation). Miało to zapobiegać wykorzystaniu radia w celach propagandowych jak w Republice Weimarskiej i w III Rzeszy. Założeniem nowego ustroju radiofonii publicznej było więc oddzielenie jej od władz państwowych i zapewnienie neutralności politycznej ${ }^{17}$. Wyrażało się to w haśle "Radio nie należy do nikogo" ${ }^{18}$.

W latach 1947-1948 w zachodnich strefach okupacyjnych tworzono rozgłośnie radiowe zorganizowane jako zakłady publicznoprawne. Poddano je kontroli rad rozgłośni — organów kolegialnych kontroli programowej. W ich skład wchodzili przedstawiciele różnych grup społecznych - delegowani w szczególności przez partie polityczne, wspólnoty religijne, związki zawodowe, zrzeszenia i instytucje edukacyjne. Uwolniło to radiofonię zarówno od wpływu państwa, jak i interesów prywatnych. Rozgłośniom postawiono zadania programowe z zakresu informacji, rozrywki i edukacji.

Do sfinansowania działalności rozgłośnie uzyskały wpływy z opłaty radiofonicznej, której poborem zajmowała w dalszym ciągu Poczta Rzeszy, a od 1947 roku jej następczyni — Poczta Niemiecka, od 1950 roku istniejąca pod nazwą Niemiecka Poczta Federalna. Jako uzupełniające źródło dochodu dopuszczono wpływy z reklam ${ }^{19}$.

14 Amtsblatt des Reichspostministeriums 1931, s. 509, 1940, s. 141.

15 A. Hesse, op. cit., s. 4, 5.

16 K. Dussel, Deutsche Rundfunkgeschichte, Konstanz 1999, s. 42.

17 F. Ossenbühl, Rundfunkprogramm, Leistung in treuhänderischer Freiheit, „Die Öffentliche Verwaltung" 1977, s. $381 \mathrm{n}$.

18 A. Hesse, op. cit., s. 10.

19 Ibidem, s. 9 n., s. 18, 19. 
Istotne znaczenie dla kontynuacji procesu utrzymania niezależności radiofonii ma art. 5 konstytucji Republiki Federalnej Niemiec, która weszła w życie 24 maja $1949 \mathrm{roku}^{20}$. Przepis ten, zawarty w rozdziale I „Prawa podstawowe”, stanowi:

1. Każdy ma prawo do swobodnego wypowiadania i rozpowszechniania swoich poglądów w słowie, piśmie i obrazie oraz do pozyskiwania bez przeszkód informacji z powszechnie dostępnych źródeł. Zapewnia się wolność prasy oraz wolność informacji za pośrednictwem radia, telewizji i filmu. Nie stosuje się cenzury.

2. Powyższe prawa podlegają ograniczeniom wynikającym z przepisów ogólnych ustaw, przepisów ustawowych o ochronie młodzieży i prawa do czci osobistej.

Równoległe regulacje są zamieszczone w konstytucjach krajów związkowych ${ }^{21}$.

Republika Federalna Niemiec uzyskała pełną suwerenność państwową na podstawie układów paryskich z 1954 roku, zawartych z trzema zachodnimi mocarstwami okupacyjnymi, podpisanych 5 maja 1955 roku. Miało to także wpływ na sytuację prawną radiofonii i telewizji. W każdym kraju związkowym utworzono odrębną radiofonię publiczną w dotychczasowej formie zakładu administracyjnego. Rady nadzorcze rozgłośni były obsadzane personalnie przez parlamenty krajów związkowych. Rozstrzyganie ważnych spraw wewnętrznych rozgłośni w zakresie programowym, osobowym, finansowym powierzono ich organom wykonawczym (radom administracyjnym). W 1950 roku rozgłośnie krajowe się zrzeszyły w ARD ${ }^{22}$. W ramach tej organizacji w 1953 roku zawarto porozumienie telewizyjne mające na celu utworzenie federalnego programu telewizyjnego, który rozpoczął działalność w 1954 roku, emitowanego przez stacje telewizyjne tworzone od 1950 roku w poszczególnych krajach związkowych.

Od 1954 roku wprowadzono system wyrównania finansowego ${ }^{23}$, umożliwiający transfery między nadawcami telewizyjnymi. Uczyniono to na dwa sposoby — jako bezpośrednie transfery finansowe między nadawcą „dającym” i ,biorącym" i zróżnicowane transfery finansowe na rzecz realizacji wspólnych zadań ${ }^{24}$.

W listopadzie 1960 roku $^{25}$ utworzono dwa zakłady publicznoprawne nadawców radia - Deutschlandfunk i Deutsche Welle. Koncepcja utworzenia federalnego nadawcy telewizji nie powiodła się, jako że zabrakło poparcia niezbędnej większości parlamentarnej. Rząd federalny utworzył więc spółkę z o.o. Deutschland Fernsehen $\mathrm{GmbH}$, której udziałowcami oprócz federacji miały być kraje związkowe. Nie przyjęły one jednak tej oferty i wystąpiły do Federalnego Sądu

20 Ustawa zasadnicza dla Republiki Federalnej Niemiec z dnia 23 maja 1949 r., BGB1 I, s. 1 ze zm.

21 Zob. G. Herrmann, M. Lausen, Rundfunkrecht. Fernsehen und Hörfunk mit Neuen Medien, München 2004, s. 71, 72.

22 Arbeitsgemeinschaft der öffentlich-rechtlichen Rundfunkanstalten in Deutschland (Wspólnota Robocza Publicznoprawnych Zakładów Radiowych w Niemczech czy Związek Niemieckich Nadawców Publiczno-Prawnych).

23 Finanzausgleich.

24 A. Hesse, op. cit., s. 13.

25 BGBl. 1960 I, s. 862. 
Konstytucyjnego o rozstrzygnięcie sporu z federacją w trybie art. 93 ust. 1 pkt 3 konstytucji. Wydany w tej sprawie wyrok z 28 lutego z 1961 roku $^{26}$, zwany telewizyjnym, miał istotny wpływ na dalszy rozwój oraz pozycję prawną radiofonii i telewizji w Republice Federalnej Niemiec.

Zdaniem sądu federacja, tworząc spółkę, naruszyła art. 30 konstytucji federalnej w związku z przepisami jej rozdziału VIII „Wykonywanie ustaw federalnych i administracja federalna", zasadę przyjaznego zachowania się federalnego $^{27}$ i art. 5 konstytucji stanowiący o wolności mediów. Artykuł 30 konstytucji ustanawia domniemanie właściwości na rzecz krajów związkowych w zakresie wykonywania zadań państwowych, o ile konstytucja nie stanowi inaczej. Jako że sąd nie znalazł takiej podstawy konstytucyjnej na rzecz federacji, stwierdził w rozpatrywanej sprawie właściwość władz krajów związkowych. Artykuł 73 pkt 7 konstytucji, określający kompetencje federacji w zakresie poczty i telekomunikacji, obejmuje zdaniem sądu tylko sprawy techniczne radiofonii i telewizji, ich regulację prawną, tworzenie i utrzymywanie urządzeń nadawczych, z wyłączeniem techniki studyjnej oraz regulacji prawnej dotyczącej audycji radiowych i telewizyjnych czy ich organizatorów. W tym stanie rzeczy sąd ustalił w rozpatrywanej sprawie właściwość krajów związkowych ${ }^{28}$. W wyniku tego wyroku utworzenie federalnej stacji telewizyjnej emitującej program II telewizji RFN nastąpiło na podstawie Umowy państwowej z dnia 6 lipca 1961 roku o utworzeniu zakładu prawa publicznego Drugi Niemiecki Program Telewizyjny (ZDF), zawartej przez wszystkie ówczesne kraje związkowe ${ }^{29}$.

Federalny Sąd Konstytucyjny wydał w następnych latach jeszcze kilka wyroków w zakresie organizacji, funkcjonowania i finansowania publicznej radiofonii i telewizji ${ }^{30}$.

W wyniku zjednoczenia Niemiec zwiększyła się liczba krajów związkowych. Wymagało to zawarcia nowych umów państwowych. Przede wszystkim należy wymienić Umowę państwową z dnia 31 sierpnia 1991 roku o radiofonii w zjednoczonych Niemczech, która weszła w życie z dniem 1 stycznia 1992 roku ${ }^{31}$. W załącznikach do tej umowy: potwierdzono dualny ustrój radiofonii i telewizji w całych Niemczech, z nadawcami publicznymi i prywatnymi; zawarto postanowienia dotyczące ARD jako wspólnego programu telewizyjnego wszystkich

26 Entscheidungen des Bundesverfassungsgerichts (BVerfGE) Nr 12, s. 205.

27 Zwana także zasadą wierności federacji, nakłada na federację i kraje związkowe obowiązek wzajemnego liczenia się z sobą i współdziałania.

28 Federalny Sąd Konstytucyjny wydał jeszcze kilka wyroków wpływających na pozycję prawną i zasady prawne finansowania publicznej radiofonii i telewizji.

29 A. Hesse, op. cit., s. 18.

30 Zob. G. Herrmann, M. Lausen, op. cit., s. 70, 71.

31 Staatsvertrag über den Rundfunk im vereintem Deutschland (RStV), GVBl. z 1991 r., s. 451. 
krajów związkowych oraz ZDF jako programu drugiego tej telewizji; sformułowano na nowo regulację o systemie opłat radiofonicznych ${ }^{32}$.

3. W RFN działa wielu publicznych nadawców o zasięgu krajowym i ponadkrajowym ${ }^{33}$. Wszyscy są zakładami administracyjnych o statusie osób prawa publicznego. Podstawy prawne ich organizacji i funkcjonowania uregulowane są w ustawowym prawie radiofonicznym, w umowach państwowych zawartych i ratyfikowanych przez kraje związkowe, a także w przepisach wewnętrznych nadawców ${ }^{34}$.

Ustrój tych zakładów jest ukształtowany wedle podobnych zasad. Ich organami są intendent, rada radiofoniczna (w ZDF rada telewizyjna) i rada administracyjna. Intendent kieruje zakładem i jest odpowiedzialny za emitowane programy. Jego organem doradczym i kontrolnym jest Rada Radiofonii, która nie ma możliwości kształtowania treści programów. Jej obowiązkiem jest jednak zapewnienie pluralizmu programowego przez umożliwienie dostępu do programów przedstawicielom ważnych grup społecznych. Rada kontroluje sposób kierowania zakładem przez intendenta, przestrzeganie ustawowych zasad programowych oraz doradza mu we wszystkich sprawach radiofonicznych. Pozycja rady jest wzmocniona jej kompetencją wyboru intendenta. Szczegółowe kompetencje rad są uregulowane w ustawach krajowych o publicznych zakładach radiofonicznych, regulujących także skład osobowy i liczbę ich członków. Są to przedstawiciele różnych zrzeszeń: związków zawodowych, organizacji politycznych, organizacji kobiecych, kościołów.

Przykładem szczegółowej regulacji prawnej jest bawarska ustawa o radiofonii ${ }^{35}$.

Zadaniem Rady Radiofonii jest reprezentowanie w radiofonii interesów ogółu i czuwanie nad tym, aby Radiofonia Bawarska wykonywała jej zadania zgodnie $\mathrm{z}$ ustawami. W tym celu rada sprawuje niezbędną kontrolę. Członkowie rady są

32 G. Herrmann, M. Lausen, op. cit., s. 72 n.

33 Rozgłośnie krajowe - Bayerischer Rundfunk (BR), Hessischer Rundfunk (HR), Mitteldeutscher Rundfunk (MDR), Norddeutscher Rundfunk (NDR), Rundfunk Berlin Brandenburg (RBB), Radio Bremen (RB), Saarländischer Rundfunk (SR), Südwestrundfunk (SWR), Westdeutscher Rundfunk (WDR), rozgłośnie o zasięgu ponadkrajowy: Deutschlandradio (DLF) nadające trzy programy oraz Deutsche Welle (DW) skierowana do słuchaczy za granicą, telewizja ARD, ZDF i ARTE. W 2014 r. publiczne radio emitowało 67 programów, a telewizja 22 programy; zob. Öffentlich-rechtliche Medien-Aufgabe und Finanzierung, Gutachten des Wissenschaftlichen Beirats beim Bundesministerium der Finanzen, 03/2014, s. 10.

34 Są to umowy dotyczące radiofonii, ARD, ZDF, radia Deutschlandfunk, opłaty radiofonicznej, finansowania radiofonii; podstawowe znaczenie ma Umowa państwowa w sprawie radiofonii i telemediów z dnia 18 grudnia 1991 r. (Staatsvertrag für Rundfunk und Telemedien (Rundfunkstaatsvertrag - RStV) vom 18. Dezember 1991), GVBl. z 2001 r., s. 502, 503, zob. W. Hahn, T. Vesting, Beck'scher Kommentar zum Rundfunkrecht, München 2008.

35 Gesetz über die Errichtung und die Aufgaben einer Anstalt des öffentlichen Rechts „Der Bayerische Rundfunk“ (Bayerisches Rundfunkgesetz - BayRG), in der Fassung der Bekanntmachung vom 22. Oktober 2003 (GVBl. s. 792). 
zobowiązani bronić wspólnych interesów radiofonii i interesów użytkowników radiofonii (abonentów). Nie są przy tym związani instrukcjami.

Rada liczy pięćdziesięciu członków, w tym w liczbie od jednego do dwu delegowanych przez środowiska czy organizacje określone w ustawie, uznane za znaczące politycznie, światopoglądowo i społecznie oraz przez Bawarski Landtag (12) i rząd bawarski (1).

Ustawa uwzględnia parytet płci przedstawicieli. Jeżeli zatem określona organizacja czy instytucja deleguje więcej niż jednego przedstawiciela, powinni to być w równej liczbie mężczyźni i kobiety. Jeśli kierowany jest jeden przedstawiciel, powinni to być na przemian mężczyzna lub kobieta. Gdy to nie jest możliwe albo nie służyłoby sprawie, należy przedłożyć przewodniczącemu rady stosowne uzasadnienie. Należy je podać do wiadomości radzie, a także opublikować na stronie internetowej Radiofonii Bawarskiej, o ile nastąpiło odchylenie od reguł równości. Członkowie są delegowani do rady każdorazowo na okres pięciu lat. Ich kadencja rozpoczyna się 1 maja. Delegująca organizacja czy instytucja może odwołać swego przedstawiciela, który przestał być jej członkiem. W takiej sytuacji jego następca jest delegowany na resztę kadencji. Kadencja delegata Landtagu rozpoczyna się z chwilą jego delegacji, a kończy z chwilą delegowania nowego przedstawiciela z początkiem nowej kadencji Landtagu. Delegowany przez Landtag przedstawiciel może być odwołany, jeżeli przestał być członkiem partii reprezentowanej w Landtagu, z której rekomendacji został delegowany. Na jego miejsce jest delegowany nowy przedstawiciel.

Rada zwykłą większością głosów wybiera intendenta i może go odwołać większością dwóch trzecich głosów. Wybiera pięciu z siedmiu członków do rady administracyjnej. Wyraża zgodę na powołanie przez intendenta dyrektorów programowych do spraw radia i telewizji, dyrektora administracyjnego, dyrektora technicznego i dyrektora prawnego, zastępcę intendenta, kierownika wydziału głównego oraz rzecznika ochrony młodzieży. Doradza intendentowi w kształtowaniu programu i w innych podstawowych problemach; zatwierdza plan gospodarczy i podejmuje uchwałę w sprawie absolutorium dla intendenta; uchwala wytyczne programowe.

Do zadań Rady Administracyjnej należy wspieranie rozwoju gospodarczego i technicznego radiofonii, a jej członkowie nie mogą reprezentować szczególnych interesów. Rada zawiera umowę o pracę z intendentem, reprezentuje Radiofonię Bawarską $\mathrm{w}$ zakresie umów $\mathrm{z}$ intendentem, a także w sporach między intendentem a radiofonią, czuwa nad prowadzeniem spraw przez intendenta, sprawdza budżet i zamknięcie roczne sporządzane przez intendenta, publikuje bilans i sprawozdanie roczne, udziela zgody na zakończenie obowiązywania, zmianę czy rozwiązanie umów o zatrudnienie, jeśli nie jest właściwy intendent.

Rada Administracyjna składa się z prezydenta Landtagu, prezydenta trybunału administracyjnego i pięciu członków wybieranych przez Radę Radiofonii. Miarodajne w kwestii wyboru powinny być kwalifikacje. Jeden z członków rady 
powinien mieć zdany egzamin na biegłego rewidenta, a jeden ukończone studia wyższe lub mieć umiejętności i doświadczenie zawodowe w zakresie gospodarki mediów.

Z punktu widzenia obiektywności czy stronniczości członków tych gremiów istotna jest regulacja w sprawie incompatibilitas. Członkami Rady Radiofonii i Rady Administracyjnej, poza wyjątkami określonymi w ustawie, nie mogą być: posłowie do Parlamentu Europejskiego, Niemieckiego Bundestagu czy parlamentu krajowego, członkowie Komisji Europejskiej, Rządu Federalnego, rządu krajowego, samorządowi wybieralni zawodowi urzędnicy i przedstawiciele kierownictwa komunalnych związków dachowych, członkowie zarządów partii politycznych szczebla federalnego i krajowego, urzędnicy lub stali współpracownicy Radiofonii Bawarskiej, osoby będące członkami organu innego publicznoprawnego organizatora radiofonii lub krajowego medialnego zakładu publicznoprawnego (osoby te mogą być delegowane do Rady Radiofonii lub wybrane do Rady Administracyjnej najwcześniej po upływie osiemnastu miesięcy po zakończeniu pełnienia wskazanych funkcji), członkowie Rady Radiofonii lub Rady Administracyjnej pełnią swe funkcje społecznie i nie otrzymują z tego tytułu żadnego honorarium, wyjątki wymagają zgody przewodniczących obydwu gremiów, członkom rad przysługuje zwrot poniesionych nakładów.

Członkiem Rady Radiofonii i Rady Administracyjnej, licząc obydwa organy, można być nie dłużej niż trzy kadencje. Członkostwo w tych organach przed 1 maja 2017 roku liczy się jako jedna kadencja. Członkowie Rady Radiofonii nie mogą być równocześnie członkami Rady Administracyjnej. Członkostwo w Radzie Radiofonii wygasa z chwilą wyboru do Rady Administracyjnej.

Zgodnie $\mathrm{z}$ zasadą jawności publikacji w formie elektronicznej na stronie internetowej Radiofonii Bawarskiej podlega: skład Rady Radiofonii i jej komisji, skład Rady Administracyjnej, porządki obrad tych organów, przedmiot i wyniki ich posiedzeń. Następuje to $\mathrm{z}$ uwzględnieniem ochrony tajemnicy przedsiębiorstwa i interesów Radiofonii Bawarskiej, uprawnionych interesów jej pracowników w ochronie ich danych osobowych, uprawnionych interesów ochrony interesów osób trzecich.

Rada Radiofonii jest organem sprawującym funkcje kontrolne. Działalność nadawców publicznych podlega także nadzorowi prawnemu rządu krajowego. W Bawarii jest on sprawowany przez krajowe ministerstwo do spraw oświaty, kultury, nauki i sztuki, a w Hesji przez kancelarię premiera. Według ustawy ingerencja nadzorcza jest dopuszczalna, gdy właściwe organy radia bawarskiego w stosownym czasie nie wykonają ich obowiązków lub wykonają je w niewystarczającym stopniu. Ministerstwo ma w takim przypadku kompetencję do wyznaczenia stosownego terminu wykonania takiego obowiązku. W Hesji jako dodatkowy środek nadzoru przewidziane jest pisemne wskazanie działań lub zaniechań naruszających ustawę radiofoniczną lub powszechnie obowiązujące przepisy. Jeżeli naruszenie prawa nie zostanie usunięte w wyznaczonym czasie, kancelaria 
może nakazać Radiofonii Heskiej przedsięwzięcie w ustalonym czasie określonych środków zaradczych. Ingerencja w sprawach programowych jest niedopuszczalna, gdyż kompetencje w tym zakresie należą do Rady Radiofonii.

Możliwość sprawowania nadzoru prawnego nad publiczną radiofonią nie budzi obecnie wątpliwości. Powołana regulacja ustawowa wykazuje jednak, że środki tego nadzoru są bardzo ograniczone. Jest to zgodne ze stanowiskiem Federalnego Sądu Konstytucyjnego, który w powołanym wyroku „telewizyjnym” przyjął, że nadawcy publiczni mogą podlegać co najwyżej ograniczonemu nadzorowi prawnemu państwa. Ważna jest jednak istota tych ograniczeń. Nadzór prawny państwa jest traktowany jako subsydiarny do kontroli wewnętrznej sprawowanej przez rady radiofonii ${ }^{36}$. Panuje zgodność co do tego, że sprawy programowe są absolutnie wyłączone spod nadzoru nawet w tych krajach związkowych, w których ustawy o radiofonii nie zawierają expressis verbis takiego przepisu ${ }^{37}$. Niedopuszczalna jest ingerencja nadzorcza w sferę wolności wyrażania poglądów. Jest to sposób na efektywne przeciwstawienie się ingerencji w konstytucyjnie gwarantowaną wolność mediów, wymagającą ochrony przed wpływem państwa. Ingerencja nadzorcza w pozostałe obszary funkcjonowania radiofonii i telewizji publicznej jest natomiast dopuszczalna tylko w sytuacji ewidentnych naruszeń prawa ${ }^{38}$. Takie ograniczenia wynikające z ustaw i z sędziowskiej wykładni prawa, a także skuteczność kontroli wewnętrznej, sprawiają, że państwowy nadzór prawny nad nadawcami publicznymi w praktyce nie jest prawie wcale stosowany ${ }^{39}$.

4. Regulacja prawna wymiaru i poboru opłat radiofonicznych się zmieniła na skutek wydania przez Federalny Sąd Administracyjny wyroku z dnia 15 marca 1968 roku $^{40}$, który nawiązał do powołanego wyroku „telewizyjnego” Federalnego Sądu Konstytucyjnego z dnia 28 lutego z 1961 roku i stwierdził, że finansowanie przedsięwzięć radiowych i telewizyjnych ma charakter organizacyjny, a więc to kraje związkowe są właściwe do regulacji prawnej opłat radiofonicznych. W związku z tym kraje te zawarły w dniu 1 stycznia 1970 roku umowę państwową o regulacji systemu opłat radiofonicznych. Wysokość tych opłat miała zostać ustalona w odrębnej umowie państwowej. W następnych latach zawierano zatem kolejne umowy państwowe w sprawach omawianych opłat, ratyfikowane przez parlamenty krajowe. W toku tych zmian w 1973 roku ARD, ZDF i Deutschlandradio zawarły porozumienie, na mocy którego utworzono wspólną instytucję

36 G. Herrmann, M. Lausen, op. cit., s. 405.

37 A. Scharf, Aufsicht bei Funk und Fernsehen, Dokumentation zum 5. Verwaltungsrichtertag, München 1977, s. 103, 110.

38 A. Hesse, op. cit., s. 173.

39 G. Herrmann, M. Lausen, op. cit., s. 407.

40 BVerGe 29, s. 214. 
Gebühreneinzugszentrale (GEZ) ${ }^{41}$, a ta z dniem 1 stycznia 1976 roku przejęła pobór opłaty radiofonicznej od Niemieckiej Poczty Federalnej ${ }^{42}$.

Obowiązek uiszczania opłaty radiofonicznej ciążył na każdym gospodarstwie domowym, a także na innych podmiotach mających odbiornik radiowy czy telewizyjny z zamiarem jego użytkowania ${ }^{43}$. Od 1 stycznia 2007 roku obowiązkiem tym objęto także nowe rodzaje urządzeń odbiorczych, jak telefony komórkowe czy komputery, umożliwiające odbiór audycji radiowych lub telewizyjnych, także w sytuacji niekorzystania z tego. Mimo wielu możliwości zwolnienia od opłat system ten napotykał nasilające się niezadowolenie społeczne ze względu na jego przymusowość i powiązanie z posiadaniem odbiorników. W toczącej się dyskusji proponowano dwa warianty — daninę obciążającą gospodarstwo domowe lub pełnoletnią osobę z własnym źródłem dochodu. Wspólne tym koncepcjom było oderwanie opłat od liczby posiadanych odbiorników. Miało to ułatwić administrowanie tymi daninami. Obciążałoby jednak także osoby niekorzystające $\mathrm{z}$ radia czy telewizjii ${ }^{44}$.

Na zlecenie nadawców ARD, ZDF i Deutschlandradio P. Kirchhof, były sędzia konstytucyjny, przygotował ekspertyzę o finansowaniu radiofonii i telewizji publicznej. Zważywszy na rozwój techniki, uznał, że dotychczasowa danina związana z urządzeniami odbiorczymi prowadzi do sprzeczności z konstytucją. Finansowanie $\mathrm{z}$ podatków (budżetowe) koliduje natomiast $\mathrm{z}$ zasadą niezależności radiofonii i telewizji od państwa. Zaproponował zatem jako jedyne możliwe wyjście przyjęcie koncepcji daniny obciążającej gospodarstwa domowe. Premierzy krajów związkowych dnia 9 lipca 2010 roku postanowili o przyjęciu takiego modelu i podpisali w grudniu 2010 roku nową umowę państwową o składce radiofonicznej ${ }^{45}$, ratyfikowaną przez parlamenty krajów związkowych w 2011 roku. Umowa ta weszła w życie od 1 stycznia 2013 roku. Poprzednie rozwiązania opierały się na koncepcji opłaty w zamian za uzyskanie zezwolenia na posiadanie i używanie odbiornika. Według aktualnej regulacji prawnej takie zezwolenie nie jest wymagane. Jako że $\mathrm{w}$ istocie pozwolenie to nie było związane z rzeczywistym używaniem, nową daninę nazwano „składką” obciążającą gospodarstwa domowe.

Od 2012 roku do sądów wnoszone są liczne skargi przeciw nowym regulacjom prawnym. Tylko w 2016 roku z tego tytułu wniesiono około czterech tysięcy skarg. Podnosi się w nich głównie naruszenie konstytucyjnej zasady równości bądź kwestionuje się kompetencje krajów związkowych do regulacji tej materii.

41 Centrala ds. Poboru Opłat.

42 Od dnia 1 stycznia 2013 r., z wejściem w życie nowych zasad finansowania radiofonii, zmieniono nazwę GEZ na „ARD ZDF Deutschlandradio Beitragsservice”, czyli ARD ZDF Deutschlandradio Serwis Składkowy.

43 Zrezygnowano z dotychczasowej konstrukcji zezwolenia na użytkowanie odbiornika.

44 Rundfunkgebühren in Deutschland. Finanzierung des öffentlich-rechtlichen Rundfunk. Ausarbeitung, Deutscher Bundestag, Wissenschaftliche Dienste 2008, WD 10-026/08, s. $11 \mathrm{n}$.

45 Rundfunkbeitragsstaatsvertrag (RBStV). 
Prawie wszystkie dotychczasowe skargi były oddalane. Sądy powoływały się na to, że Federalny Sąd Konstytucyjny orzekał już przed reformą o konstytucyjności ustawowego regulowania problematyki opłat radiowo-telewizyjnych, któremu zarzucano zagrożenie niezależności radiofonii od państwa ${ }^{46}$. Sąd przyjął w wyroku z dnia 22 lutego 1994 roku $^{47}$, że taka regulacja ustawowa jest dopuszczalna pod warunkiem zapewnienia zarówno prawidłowego funkcjonowania radiofonii publicznej, jak i skutecznego wykluczenia politycznego wpływu na kształtowanie programów. Powołując się na swe wcześniejsze orzecznictwo w sprawach praw podstawowych, stwierdził, że występujący w rozpatrywanej sprawie nie ma wystarczających gwarancji materialnoprawnych, co należy zrekompensować regulacją proceduralną. Ze względu na niemożność ustalenia konkretnej kwoty opłaty radiofonicznej w prawniczej wykładni art. 5 konstytucji federalnej należy stworzyć procedury normatywne pozwalające na ustalenie zapotrzebowania finansowego radiofonii. $Z$ konstytucyjnego punktu widzenia ważne jest zapewnienie nadawcom publicznym środków niezbędnych do wykonywania ich zadań i wykluczenie politycznego wpływu na kształtowanie programów. Sąd stwierdził, że może to być spełnione przez wprowadzenie wielostopniowego i kooperacyjnego postępowania.

Niezależnie od regulacji prawnej daniny radiofonicznej w Niemczech obowiązuje także odrębna regulacja prawna o zasadach finansowania radiofonii i telewizji. Wyrok Federalnego Sądu Konstytucyjnego miał wpływ na jej treść. W jego następstwie opracowano Umowę państwową o finansowaniu radiofonii z dnia 26 sierpnia-12 września 1996 roku, która po podpisaniu przez premierów krajów związkowych i ratyfikacji przez parlamenty krajowe weszła do porządku prawnego krajów związkowych ${ }^{48}$.

Do realizacji zadań wynikających z umowy utworzono Komisję ds. Ustalania Zapotrzebowania Finansowego jako organ właściwy do przyjmowania i badania zgłoszeń nadawców publicznych w sprawie ich zapotrzebowania finansowego oraz ustalania jego wysokości ${ }^{49}$. W jej skład wchodzi szesnastu niezależnych ekspertów delegowanych na pięć lat przez premierów krajów związkowych, przy zachowaniu klucza specjalizacji, który przedstawia się następująco: trzech ekspertów o kwalifikacjach biegłych rewidentów bądź doradców gospodarczych, dwóch z zakresu zarządzania przedsiębiorstwem - w sprawach personalnych, inwestycyjnych albo racjonalizacji, dwóch ze szczególną wiedzą z zakresu prawa radiofonicznego i kwalifikacjami umożliwiającym objęcie urzędu sędziowskiego, trzech z zakresu gospodarki mediów lub nauki o mediach, jeden z zakresu techniki radiofonicznej, pięciu z krajowych trybunałów obrachunkowych.

\footnotetext{
46 P. Badura, Rundfunkfreiheit und Finanzautonomie, Frankfurt 1986, s. 30 n.

47 BVerfGE 90, s. 60, 87 n.

48 Rundfunkfinanzierungsstaatsvertrag (RfFinStV), GVB1. 2001, s. 566, 567.

49 Kommission zur Überprüfung und Ermittlung des Finanzbedarfes der Rundfunkanstalten
} (KEF). 
Komisja, jak widać, jest reprezentacją szerokiego spektrum ekspertów z zakresu gospodarki, prawa i spraw technicznych mediów, a ustalenie jej składu osobowego wymaga współdziałania premierów krajów związkowych. Jej członkami nie mogą być: członkowie bądź urzędnicy instytucji Unii Europejskiej lub organów konstytucyjnych federacji i krajów związkowych, członkowie gremiów i urzędnicy krajowych zakładów radiofonii, ARD i ZDF, Deutschlandradio, Europejskiego Kanału Kulturalnego „Arte”, krajowych zakładów medialnych i nadawców prywatnych, jak również pracownicy przedsiębiorstw — pośrednich albo bezpośrednich udziałowców w wymienionych podmiotach, w rozumieniu § 28 umowy państwowej radiofonicznej.

Postępowanie przed Komisją jest trójetapowe. Pierwszy etap obejmuje przyjmowanie wniosków, drugi - ich fachowe badanie i ocenę z punktu widzenia zgodności z zadaniami radiofonii, zasadami gospodarności i oszczędności, z zapewnieniem aktywnego uczestnictwa zainteresowanych nadawców publicznych. Następnie Komisja przygotowuje projekt sprawozdania, który jest przesyłany ARD, ZDF i Deutschlandradio oraz komisji radiofonicznej krajów związkowych w celu przedstawienia stanowiska, które jest następnie ujęte w końcowym sprawozdaniu Komisji. Na trzecim etapie, na podstawie jej sprawozdania, jest ustalana składka radiofoniczna w trybie umowy państwowej krajów związkowych. Prawodawca jest jednak w dużym stopniu związany ustaleniami Komisji. Wynika to z wyroku Federalnego Sądu Konstytucyjnego, według którego odstępstwo może wynikać tylko ze względu na dopływ nowych informacji, czyli zmiany stanu faktycznego, czy z socjalnych wymogów odpowiedniego obciążania użytkowników radiofonii oraz powinno być uzasadnione. Należy także uwzględnić zasadność składki oraz zwolnienia z jej opłacania ${ }^{50}$. W praktyce ustalenia Komisji traktowane są jako wiążące.

Umowa o finansowaniu ustala procentowy udział nadawców publicznych w kwocie środków pochodzących ze składek, czyli nadawców krajowych, a ponadto Deutschlandradio, ARD, ZDF jako ich instytucje wspólne. Umowa reguluje także procedurę płatności i zasady finansowania nowo utworzonych nadawców. Podział środków finansowych pochodzących ze składek, oparty na liczbie abonentów, nie zapewnia jednak wystarczającego zaopatrzenia finansowego mniejszym nadawcom. Aby tego uniknąć, elementem omawianego systemu prawnego finansowania jest mechanizm wyrównawczy, finansowany ze środków nadawców publicznych. Jego początki sięgają 1949 roku, wówczas w tej kwestii umowę zawarli dwaj nadawcy, Nordwestdeutsche Rundfunk i Radio Bremen. W 1953 roku ARD uznała wyrównanie finansowe za zadanie wspólne zrzeszonych nadawców krajowych. Aktualnie jest to uregulowane w § $12 \mathrm{RStV}$ i $\S 12 \mathrm{n}$. RfFinStV.

Według § $12 \mathrm{RStV}$ wyposażenie finansowe powinno umożliwiać radiofonii publicznoprawnej wykonywanie jej konstytucyjnych i ustawowych obowiązków,

50 F. Fechner, Medienrecht, Tübingen 2017, s. 96 n. 
a w szczególności utrzymać ich stan aktualny oraz rozwój. Wyrównanie finansowe między krajowymi zakładami radiofonicznymi jest elementem systemu finansowego ARD, który zabezpiecza w szczególności wykonywanie zadań przez Saarländischer Rundfunk i przez Radio Bremen. W sprawie wielkości środków wyrównania finansowego i jego dopasowania do składki radiofonicznej następuje odesłanie do umowy państwowej o finansowaniu radiofonii.

Umowa ta stanowi, że krajowi nadawcy publiczni zrzeszeni w ARD są uprawnieni i obowiązani do wprowadzenia stosownego wyrównania finansowego zapewniającego wykonywanie nadrzędnych zadań radiofonii publicznej i takich zadań poszczególnych nadawców, które powinny być podejmowane z uwagi na ich znaczenie dla całej radiofonii, a także to, aby każdy nadawca mógł tworzyć i nadawać wystarczający program. Kwota środków przeznaczonych na wyrównanie finansowe jest ustalana w ramach ARD przez krajowych nadawców publicznych stosownie do ich siły finansowej, w drodze porozumienia określonego w $\S 15$. Wynosi ona 1,6\% wpływów netto ARD z tytułu składki radiofonicznej i jest dzielona w wysokości 50,92\% na rzecz Saarländischer Rundfunk i 49,08\% na rzecz Radio Bremen. W granicach tak ustalonych zasad wyrównanie finansowe jest w kwestiach szczegółowych przedmiotem porozumienia między nadawcami krajowymi. Nadawcy, którzy nie dokonują wpłat z tytułu wyrównania finansowego, są obowiązani do wnoszenia składek na rzecz przedsięwzięć wspólnych publicznej radiofonii i telewizji. Ten udział powinien być uwzględniony w porozumieniu.

Umowy państwowe o finansowaniu radiofonii zawarte przez kraje związkowe przewidują obowiązek wykonania zastępczego, jeśliby na początku roku obrachunkowego nie zostało zawarte omawiane porozumienie. Wówczas o kwocie wyrównania finansowego, obowiązkach i uprawnieniach w tym zakresie rozstrzygają rządy krajowe większością dwu trzecich głosów. Każdy rząd krajowy ma tyle głosów, ile ma miejsc w Bundesracie. Aż do podjęcia kolejnej uchwały stosowane są porozumienie lub uchwała z poprzedniego roku. Zapewnia to ciągłość finansowania publicznej radiofonii i telewizji w Niemczech także nadawców, których wpływy finansowe uzyskane na zasadach ogólnych byłyby niewystarczające do wykonania ich zadań.

Prawna regulacja finansowania nadawców publicznych oprócz gwarancji obejmuje także ograniczenia. Chodzi o emisję reklam będących dla mediów prywatnych podstawowym źródłem finansowania ich działalności, a dla mediów publicznych uzupełniającym. Kwestia ta jest uregulowana prawnie w powoływanej już Umowie państwowej z dnia 31 sierpnia 1991 roku o radiofonii w zjednoczonych Niemczech.

Według tych przepisów reklamą jest każda wypowiedź w trakcie wykonywania handlu, przemysłu, rzemiosła lub wolnego zawodu, nadawana odpłatnie lub za podobnym świadczeniem wzajemnym, albo jako autoreklama, której celem jest zbyt towarów albo odpłatne świadczenie usług. Każda odpłatna wzmianka czy prezentacja jest jednoznaczna z reklamą. Niedozwolona jest reklama wpro- 
wadzająca w błąd, szkodząca interesom konsumentów, ich zdrowiu i bezpieczeństwu, reklama polityczna, światopoglądowa i religijna, a także kryptoreklama. Autoreklama nadawców oraz treści emitowane nieodpłatnie w służbie publicznej, łącznie $\mathrm{z}$ apelami w sprawie zbiórek pieniężnych na cele dobroczynne, jak również informacje o obowiązkach ustawowych, nie są zaliczane do limitu antenowego czasu reklamowego. Maksymalny czas emisji reklam w ciągu godziny nie może przekraczać $20 \%$, czyli 12 minut.

Sponsoring, do którego zaliczane są także krótkie audycje, na przykład prognoza pogody, jest dozwolony, jeżeli sponsor nie wpływa na treść audycji i jeżeli jest wzmiankowany na początku lub końcu audycji, ale bez reklamowania jego produktów. Nie mogą być sponsorowane wiadomości i audycje o wydarzeniach politycznych.

Zasadniczo reklama powinna być nadawana między audycjami, wyraźnie oddzielona od programów redakcyjnych, aby wykluczyć związek między nimi a reklamą. Ma to stanowić gwarancję niezależności kształtowania programów i wykluczenia merytorycznego wpływu reklamy na programy. $Z$ tego powodu muszą być także oznaczone reklamy ciągłe, nadawane wielokrotnie. W spotach reklamowych nie mogą występować spikerzy i moderatorzy programów.

$\mathrm{Z}$ finansowego punktu widzenia są jednak istotne większe ograniczenia czasowe nakładane na nadawców publicznych w porównaniu z nadawcami prywatnymi. W programach telewizyjnych ARD i ZDF jest dopuszczalna emisja reklam średniorocznie w wymiarze do 20 minut dziennie w dni robocze, nie licząc czasu antenowego na lokowanie produktów i wzmianek o sponsorach. Nie w pełni wykorzystany czas reklamowy może być wykorzystany najwyżej w wymiarze 5 minut w dni robocze. Reklamy nie mogą być nadawane po godzinie 20.00, a także w niedziele i dni świąteczne uznane na całym obszarze RFN. Dotyczy to także sponsoringu. W innych programach telewizji publicznej emitowanych przez ARD i ZDF na całym terytorium RFN, jak również trzecich programach telewizji, reklama jest niedopuszczalna.

Kraje związkowe mają prawo ustalenia czasu reklamowego publicznych nadawców radiowych w wymiarze do 90 minut dziennie w dni robocze. Niezależnie od tego ustalenia mogą być zachowane regulacje czasowe w tym zakresie, ustalone w krajach związkowych przed dniem 1 stycznia 1987 roku.

5. Z przedstawionych rozważań wynika, że publiczna radiofonia i telewizja w Niemczech tworzą złożony system organizacyjny uwarunkowany federalnym ustrojem państwa. Jest bowiem przedmiotem właściwości krajów związkowych, z których większość ma własnych nadawców. Działają także nadawcy usytuowani ponad krajami związkowymi. Mimo takich uwarunkowań cały system działa poprawnie. Liczba nadawców publicznych i ich usytuowanie nie przekłada się wprost na mnogość rozwiązań prawnych. Są one bowiem zharmonizowane dzięki stworzeniu prawnych procedur współdziałania krajów związkowych w tej materii. 
Wszyscy nadawcy są zorganizowani w formie zdolnych prawnie zakładów administracyjnych. W toku kształtowania się regulacji prawnej tych mediów kwestie budzące wątpliwości i spory między krajami związkowymi a federacją zostały rozstrzygnięte na drodze sądowej, szczególnie przez Federalny Sąd Konstytucyjny i przez Federalny Sąd Administracyjny. Rozstrzygnięcia sądów nie były kwestionowane i stały się wiążącymi wytycznymi w procesie legislacyjnym.

Należy podkreślić udane oddzielenie publicznej radiofonii i telewizji w Niemczech od wpływów państwa. Zasada oddalenia od państwa przyświecała całemu procesowi kształtowania się publicznej radiofonii i telewizji w Niemczech. Sterowanie tymi mediami przez większość rządzącą federacją jest niemożliwe ze względu na usytuowanie ich w krajach związkowych. Na poziomie tych krajów podstawowe kompetencje znajdują się natomiast w zakresie właściwości rad radiofonicznych, których skład osobowy jest dokonywany według klucza ustawowego skutecznie uniemożliwiającego wpływ polityków na linię programową nadawców. System finansowania mediów publicznych jest oparty na składce obciążającej gospodarstwa domowe i nie przewiduje transferów z budżetu federacji czy z budżetów krajów związkowych. Sprawia to, że publiczna radiofonia i telewizja w Niemczech są niezależne od państwa, zarówno na poziomie federacji, jak i krajów związkowych.

\section{THE ORGANIZATION AND FINANCING OF A PUBLIC RADIO AND TELEVISION IN THE FEDERAL REPUBLIC OF GERMANY}

\section{Summary}

In the Weimar Republic and in the Third Reich, radio broadcasting was dependent on the government. The Federal Republic of Germany, on the other hand, created a legal system that provided the mass media with legal and factual independence. The system of radio and television was influenced by the case law of the Federal Constitutional Court. The public radio and television broadcasters include national broadcasters and joint broadcasters of federal states, organized as public-law establishments with legal personality. The management of broadcasters has been implemented basing on similar principles. The radio broadcasting board is a constitutive and controlling body, the administrative board and the authorizing officer are executive organs. The national radio board consists of people delegated by the parliament, national government, circles and organizations which are significant politically, ideologically and socially, according to the statutory key. The board of Deutschlandradio, a corporation associating ARD, ZDF and national broadcasters, consists of representatives of the federal states, the federal government and social organizations. The radio board selects the majority of the members of the administrative board, selects and dismisses the authorizing officer, consents to the casting of the broadcaster's management positions, adopts program guidelines, advises the authorizing officer in shaping the program and other basic matters, approves the economic plan, adopts the discharge resolution. The administrative board supports the broadcaster's economic development, concludes an employment contract with the authorizing officer, settles disputes between the authorizing officer and the broadcaster, supervises the management of cases by the authorizing officer, controls the budget and annual closure drawn 
up by the authorizing officer, publishes the balance sheet and the annual report, takes decisions on contracts if there is no competent authorizing officer. The broadcasters are legally supervised (by the competent government or minister). The internal control exercised by the radio board plays a fundamental role in the area of ensuring compliance with the law. German radio and television is financed by levies - initially from fees, and starting on 1.01.2013 from contributions levied on households. There is financial equalization in public radio and television. Such a system of financing provides the public media with independence and ensures the implementation of their statutory tasks, in particular the fulfilment of the public mission.

Keywords: radio broadcasting, television, public mission, state contract, public-law institution, radio board, administrative board, authorizing officer, fee, contribution

\section{BIBLIOGRAFIA}

Badura P., Rundfunkfreiheit und Finanzautonomie, Frankfurt 1986.

Bausch H., Der Rundfunk im politischen Kräftespiel der Weimarer Republik 1923-1933, Tübingen 1956.

Brack H., Die Organisation der überordneten Aufgaben des Rundfunks, [w:] H. Brack, G. Herrmann, H.P. Hilling, Organisation des Rundfunks 1948-1962, Hamburg 1962.

Bremer E., Esser M., Hoffmann M., Der Rundfunk in der Verfassungs- und Wirtschaftsordnung in Deutschland, Baden-Baden 1992.

Dussel K., Deutsche Rundfunkgeschichte, Konstanz 1999.

Fechner F., Medienrecht, Tübingen 2017.

Hahn W., Vesting Th., Beck'scher Kommentar zum Rundfunkrecht, München 2008.

Herrmann G., Lausen M., Rundfunkrecht. Fernsehen und Hörfunk mit Neuen Medien, München 2004.

Hesse A., Rundfunkrecht, München 1999.

Ossenbühl F., Rundfunkprogramm, Leistung in treuhänderischer Freiheit, „Die Öffentliche Verwaltung" 1977.

Pohle H., Der Rundfunk als Instrument der Politik, Hamburg 1955.

Scharf A., Aufsicht bei Funk und Fernsehen, Dokumentation zum 5. Verwaltungsrichtertag, München 1977. 